\title{
Administration of testosterone inhibits initiation of seminal tubule growth and decreases Sertoli cell number in the earliest period of rat's postnatal development
}

\author{
Renata Walczak-Jędrzejowska ${ }^{1}$, Jolanta Słowikowska-Hilczer ${ }^{2}$, \\ Katarzyna Marchlewska ${ }^{2}$, Elżbieta Oszukowska ${ }^{1}$ and Krzysztof Kula ${ }^{1}$
}

Departments of Andrology ${ }^{1}$ and Reproductive Endocrinology ${ }^{2}$, Medical University of Lodz, Poland

\begin{abstract}
Sertoli cell (SC) number determines testes size and their capacity to produce spermatozoa. In the rat SC proliferate until $15^{\text {th }}$ postnatal day (PND). Their proliferation is stimulated by FSH and inhibited by estradiol, but the role for androgens is uncertain. In this study we analyzed the effects of testosterone administration on testes growth and SC number in relation to timing of the treatment. Male rats were injected with $2.5 \mathrm{mg}$ of testosterone propionate (TP) from birth until $5^{\text {th }}$ PND and autopsied either on $6^{\text {th }}$ PND [TP1-5(6)] or on $16^{\text {th }}$ PND [TP1-5(16)] (transient administration). Other rats received TP from birth until 15 th PND [TP1-15] or between $5^{\text {th }}$ and $15^{\text {th }}$ PND [TP5-15] continuously and were autopsied on day $16^{\text {th }}$. Control groups $(\mathrm{C})$ received vehicle. In the Cs serum level of estradiol was 20 -fold higher $(\mathrm{p}<0.001)$ and FSH was 1,7-fold higher $(\mathrm{p}<0.05)$ on $6^{\text {th }}$ PND than on $16^{\text {th }}$ PND, while testosterone did not change. After TP blood level of testosterone increased 2200-fold on $6^{\text {th }}$ PND $(p<0.05)$, and 8-fold on $16^{\text {th }}$ PND. In turn, continuous TP administrations resulted on $16^{\text {th }}$ PND in the increase in testosterone serum level by 2000-times of C without influence on FSH. While the treatment from birth either during initial 5 days or continuously until $15^{\text {th }}$ day decreased testicular weight $(p<0.001)$, tubule length $(p<0.05)$ and SC number $(p<0.001)$, the treatment initiated on $5^{\text {th }}$ PND had no effects. TP reduced serum estradiol level on $6^{\text {th }}$ PND by 13 -fold $(p<0.01)$, but doubled it on $16^{\text {th }}$ PND. Conclusion: Neonatal rats secrete estradiol and FSH in the amounts greatly extending those presented during further development. Testosterone inhibits testicular growth and SC number acting during first 5 neonatal days by decreasing FSH secretion, but is not effective during further development. Direct inhibitory influence of testosterone or trough its increased aromatisation to estradiol beyond neonatal period may be responsible for sustained inhibition of testes growth and SC number during infancy.
\end{abstract}

Key words: testosterone, estradiol, FSH, testicular growth, Sertoli cell number

\section{Introduction}

In several European countries $20 \%$ or more of young men may have abnormally low sperm counts relative to World Health Organization criteria [1]. As each Sertoli cell (SC) can support a finite number of germ cells, the number of SCs is a key factor in determining testis size and the number of spermatozoa in adulthood [2].

In rats, SC proliferation is confined to the fetal, neonatal and infantile period and ceases at $15^{\text {th }}$ postna-

Correspondence: K. Kula, Department of Andrology, Medical University of Lodz, PL 91-425, 5 Sterling str, Lodz, Poland; tel./fax.: (+4842) 6330705, e-mail: kkula@csk.umed.lodz.pl tal day (PND). It coincides with spermatogenic onset and the initiation of spermatogenesis up to the first meiosis [3].

The main hormone that positively regulates number of SCs is FSH. Treatment with FSH of either intact neonatal rats [4], or mouse lacking LH activity [5] evidenced increase of final number of SC. Consequently, in animals lacking FSH activity (FSHRKO, FSHKO mice) there was a reduction in the final number of SC [6]. The key role of FSH in setting the final size of SC population in adulthood has been attributed to stimulation of SCs proliferation rather than a survival $[2,7]$.

The view that FSH is exclusive hormone stimulating $\mathrm{SC}$ proliferation has been challenged by recent findings demonstrating that androgens may promote 
SC proliferation in fetal and early postnatal life in mammals [8]. However, both reduced and excessive fetal testosterone levels [8,9], or ablation of androgen receptor (AR) action in ARKO mice [10], can lead to decrease in SC numbers.

In the present study we analyzed the impact of postnatal testosterone administration on testis growth and $\mathrm{SC}$ number in newborn rats in the windows of time when AR on SCs is still absent and during the first developmental appearance of AR on SCs [11]. The possible intermediation of FSH or estradiol was tested by measuring blood levels of these hormones.

\section{Materials and methods}

Animals and hormone treatment. Male Wistar rats, born on the same day, were randomly divided into experimental groups of 7 to 9 animals. Each group was kept in a separate cage together with lactating female. Animals were maintained at stable temperature $\left(22^{\circ} \mathrm{C}\right)$ and diurnal light-dark cycles (12L:12D) with free access to food and water. Male rats were daily injected with $2.5 \mathrm{mg}$ of testosterone propionate (TP) (Testosteronum propionicum, Jelfa, Poland) from birth until $5^{\text {th }}$ PND and autopsied either on $6^{\text {th }}$ PND [TP1-5(6)] or on 16 th PND [TP1-5(16)] (transient administration). Other animals received TP continuously either from a day of birth until 15 th PND [TP1-15] or between $5^{\text {th }}$ and $15^{\text {th }}$ PND [TP5-15] and were autopsied on day $16^{\text {th }}$. Control groups $(\mathrm{C})$ received vehicle (olive oil, Sigma, USA).

The dose of TP applied here was tested before in prepubertal rats and had no effect on FSH secretion [12] and moreover, it appears that this dose can provide satisfactory filtration of steroid to the testes [13].

Experiment was performed in accordance with Polish legal requirements, under the license given by the Commission of Bioethics at the Medical University of Lodz, Poland.

Processing of the tissue. Animals autopsied on $6^{\text {th }}$ or $16^{\text {th }}$ PND were anaesthetised with methohexital sodium (Brietal, Eli Lilly, USA) and fentanyl (Fentanyl, Polfa, Poland). Blood samples were taken by cardiac puncture for hormonal analysis. 16-day old animals were weighed at the autopsy. Then the testes were excised, weighed and after fixation in Bouin's solution for up to 24 hours processed through graded alcohols and embedded in paraffin wax blocks. $5 \mu \mathrm{m}$ thick sections of paraffin-embedded testes taken from equatorial cross-sections of the organ were used for histology.

Hormonal assays. After centrifugation, blood serum was collected, frozen and stored at $-20^{\circ} \mathrm{C}$ until assays. All samples were measured in the same assay. Rat FSH ( $\mathrm{rFSH}$ ) concentrations were determined by double antibody radioimmunoassay (Amersham, UK) with the sensitivity of $1.0 \mathrm{ng} / \mathrm{ml}$. Concentrations of testosterone and estradiol were determined by competitive immunoassay technique (OrthoClinical Diagnostic Amersham, UK). The sensitivities were $0.01 \mathrm{ng} / \mathrm{ml}$ for testosterone and $2.7 \mathrm{pg} / \mathrm{ml}$ for estradiol.

Morphometry of the testes. Sections $5 \mu \mathrm{m}$ thick from equatorially transsected paraffin embedded organs were stained with haematoxylin and eosin. Morphometric analyses were performed using image analysis software LxAND v3.60HM (Logitex, Lodz, Poland). Diameters of 30 seminal tubules cross-sections were measured for each animal. The volume density $(\mathrm{Vv})$ of the seminiferous tubules was obtained by point counting as it was described elsewhere [4]. Randomly selected, 10 subsequent sections of the testis per animal were examined using image analysis software, which was able to overlap a square lattice containing 441 intersections on microscopic picture at a magnification of $200 \times$. The number of intersections on the examined structure over the entire tissue section was counted by predetermined and systematic movement of sections across the grid without overlap. Vv was obtained by dividing the sum of points falling on tubular transsections by the total number of points over the tissue. The results were expressed as a percentage. In the same way the volume density of interstitial tissue of the testes was calculated. Absolute volume of the seminiferous tubules $(\mathrm{V})$ was determined by multiplying $\mathrm{V}_{\mathrm{v}}$ by fresh testis volume $(\mathrm{Vt})$ : $\mathrm{V}=\mathrm{VV}_{\mathrm{V}} \times \mathrm{Vt}$. The specific gravity of testicular tissue is about 1.0, so we used the values obtained for testicular weight as being equivalent to fresh testicular volume. The total length of the seminiferous tubule (L) was calculated using the transformed standard equation for a tube model $(\mathrm{L}=\mathrm{V} / \pi \mathrm{r} 2)$, where $\mathrm{V}$ was the seminiferous tubule volume and $\mathrm{r}$ is the radius of the tubule [4].

Sertoli cell number. Sertoli cells were identified on the basis of morphological characteristics [14]. The number of Sertoli cells was determined in 50 randomly chosen round cross sections of seminiferous tubules for each animal. Firstly, the diameter of 50 nuclei of cells was measured using image analysis software LxAND v3.60HM (Logitex, Lodz, Poland). Due to the irregular shape the nuclei diameter was estimated as the average of the height and width measurements. Then the count was corrected for section thickness and nucleus diameter by the method of Abercrombie [15] and the result was expressed per cross section of seminiferous tubule. The total number of Sertoli cells per testis was calculated from the product of total length of seminiferous tubule and cell numbers expressed per cross section [16].

Statistical analysis. Distribution of the data was analysed using Shapiro-Wilk's test. All data were normally distributed. Statistical analysis of the data was performed using one-way ANOVA followed by a post hoc test (Scheffe test). Data were presented as mean \pm SD. Differences were considered significant at $\mathrm{p}<0.05$.

\section{Results}

\section{Serum hormone levels}

In the control groups serum level of estradiol was 20fold higher $(p<0.001)$ and $r$-FSH was 1,7 -fold higher $(p<0.05)$ on $6^{\text {th }}$ PND than on $16^{\text {th }}$ PND, while testosterone did not change (Table 1). Table 1 presents also mean serum levels of hormones measured at the days of autopsy after TP administration. In TP1-5(6) testosterone increased 2245 -fold $(\mathrm{p}<0.001)$, the level of estradiol drop to $8 \%(\mathrm{p}<0.001)$, and $\mathrm{r}-\mathrm{FSH}$ to $71 \%$ $(\mathrm{p}<0.05)$ of C. Transient TP administration [TP15(16)] did not influenced, but continuous administration increased 2064-fold in TP5-15 $(\mathrm{p}<0.001)$ and 2200 -fold in TP1-15 ( $<<0.001)$ blood level of testosterone on the $16^{\text {th }}$ PND. Serum estradiol was doubled in TP1-5(16), TP5-15 and TP1-15 $(\mathrm{p}<0.05-$ $\mathrm{p}<0.001$ ), while r-FSH did not change.

\section{Testes weights, morphometry and Sertoli cell number on $16^{\text {th }}$ PND}

After transient TP administration testes weight was reduced to $65 \%$ of $\mathrm{C}$ [TP1-5(16)], but continuous 
Table 1. Serum levels of r-FSH, testosterone and estradiol in rats autopsied on $6^{\text {th }}$ PND treated with vehicle [C(6)], or $2.5 \mathrm{mg}$ of testosterone propionate (TP) from the 1st till $5^{\text {th }}$ PND [TP1-5(6)] and in rats autopsied on $16^{\text {th }}$ PND treated with vehicle [C(16)] or 2.5 mg of testosterone propionate (TP) in different periods of neonatal life [TP1-5(16), TP1-15, TP5-15] Values are presented as mean \pm SD.

\begin{tabular}{|c|c|c|c|c|}
\hline \multicolumn{2}{|c|}{$\begin{array}{c}\text { Treatment } \\
\text { (no of animals) }\end{array}$} & $\begin{array}{l}\mathrm{r}-\mathrm{I} \text { SHI } \\
\mathrm{ng} / \mathrm{ml}\end{array}$ & $\begin{array}{l}\text { Testosterone } \\
\mathrm{ng} / \mathrm{ml}\end{array}$ & $\begin{array}{l}\text { Listradiol } \\
\mathrm{pg} / \mathrm{ml}\end{array}$ \\
\hline $\begin{array}{l}\mathrm{C}(6) \\
\mathrm{TP} 1-5(6)\end{array}$ & $\begin{array}{l}\text { (7) } \\
\text { (7) }\end{array}$ & $\begin{array}{l}6.40 \pm 2.83^{\mathrm{f}} \\
4.57 \pm 1.26^{\mathrm{b}}\end{array}$ & $\begin{array}{c}0.20 \pm 0.10 \\
448.98 \pm 57.40^{\mathrm{a}}\end{array}$ & $\begin{array}{c}1084.87 \pm 425.87^{\mathrm{e}} \\
83.98 \pm 39.22^{\mathrm{a}}\end{array}$ \\
\hline $\begin{array}{l}\text { C(16) } \\
\text { TP1-5(16) } \\
\text { TP1-15 } \\
\text { TP5-15 }\end{array}$ & $\begin{array}{l}(9) \\
(7) \\
(7) \\
(8)\end{array}$ & $\begin{array}{l}3.79 \pm 1.71 \\
3.30 \pm 1,51 \\
3.67 \pm 1.00 \\
3.46 \pm 1.00\end{array}$ & $\begin{array}{c}0.24 \pm 0.08 \\
2.38 \pm 0.60 \\
528.87 \pm 114.00^{\circ} \\
495.37 \pm 47.86^{\circ}\end{array}$ & $\begin{array}{c}54.97 \pm 33.45 \\
118.91 \pm 54.80^{\mathrm{d}} \\
122.62 \pm 49.12^{\mathrm{d}} \\
143.28 \pm 52.55^{\mathrm{c}}\end{array}$ \\
\hline
\end{tabular}

Rats autopsied on $6^{\text {th }} \mathrm{PND}:{ }^{\mathrm{a}} \mathrm{p}<0.001,{ }^{\mathrm{b}} \mathrm{p}<0.05$ vs. $\mathrm{C}(6)$;

Rats autopsied on $16^{\text {th }}$ PND: ${ }^{c} \mathrm{p}<0.001$; $\mathrm{p}<0.05$ vs. $\mathrm{C}(16)$; ${ }^{\mathrm{e}} \mathrm{p}<0.001,{ }_{\mathrm{f}}^{\mathrm{f}}<0.05-\mathrm{C}(6)$ vs. $\mathrm{C}(16)$.

administration produced diverse effects: reduction in TP1-15 $(\mathrm{p}<0.001)$ and no change in TP5-15 (Fig. 1A). Similarly, mean seminiferous tubules diameter was reduced to $94 \%$ of $\mathrm{C}(\mathrm{p}<0.05)$ and seminiferous tubule length to about $65 \%$ of $\mathrm{C}(\mathrm{p}<0.05)$ in TP1-5(16) $(p<0.05)$ and TP1-15 $(p<0.05)$ and were not influenced in TP5-15 (Fig. 1B,C). Mean SC number that was reduced to $70-75 \%$ of $\mathrm{C}$ in TP1-5(16) and in TP1-15 $(p<0.001)$, did not change in TP5-15 (Fig. 1D).

There was no change in the volume density of interstitial tissue after all treatments (data not shown).

\section{Discussion}

We have shown here that high levels of serum testosterone (more than 2000-fold increase) after TP administration inhibited testes growth and SC numbers when acting during the first 5 neonatal days. Namely, when on $16^{\text {th }}$ PND continuous administration of testosterone since birth produced the same effect like administration during first 5 PNDs, the administration of testosterone between $5^{\text {th }}$ and $15^{\text {th }}$ PNDs had no effect.

We have shown here that neonatal rats secrete estradiol in the amounts greatly extending those presented during further infantile period of the development. The source are presumably testes as high aromatase activity in SC is presented from late fetal life [17] and is subsequently translocated into Leydig cells [18]. The physiological significance of high rate of estradiol production in SC of neonatal rats would be stimulation of the multiplication of gonocytes [19] as well as of the first spermatogonia [20,21].

FSH is a main hormone responsible for SC proliferation [2,7], and the effect of FSH can be eliminated by simultaneous administration of FSH with high dose of estradiol benzoate in immature rats [7]. However, we have shown here that decrease in serum estradiol during first 5 PNDs by TP treatment resulted in decrease in SC number on $16^{\text {th }}$ PND. The explanation would be decreased FSH secretion. In turn, in further development, TP stimulated blood level of estradiol associated with inhibition of testicular growth and SC number. The increase in estradiol level might contribute to sustained, reduced number of SCs in infantile rats in the period that follows neonatal one. Our data suggests that inhibitory effect of TP on testis growth and SC number seems to be dependent on the inhibition of FSH secretion in neonates followed by increased biosynthesis of estradiol in further development.

FSH is recognized as the main hormone activating SCs proliferation during early postnatal life rather than stimulating their survival $[22,23]$. Deficient androgen action in the fetal rat testis results in approximately halving of SC number at birth [8]. Other studies demonstrated, however, that excess of testosterone during fetal development had detrimental effects on sperm concentration and motility in adult sheep [9].

In the pioneering study of Robbaire et al. [13] it has been shown that steroid hormones, when exogenously administered, filter into the testis only when a circulating threshold is achieved. In our study the level of blood testosterone fairly exceeded those observed in Robbaire's study, suggesting possibility of filtration of exogenous testosterone to the testis. Doubled level of estradiol seen on $16^{\text {th }}$ PND, with no changes in FSH levels, may suggest that it was a consequence of increased intratesticular testosterone as a substrate for synthesis of estradiol. In 15-day-old rat interstitial tissue possesses around $10 \%$ of Leydig cells morphologically similar to those present in the adult rats [24], where testosterone enhances aromatase gene expression [25].

In our earlier study we have shown that the administration of testosterone to immature rats did not cause any changes in SC apoptosis [26]. The influence of androgens on SC proliferation during the neonatal period was suggested based on the study on hypogonadal mice (hpg) with depleted FSH and LH, and consequently testosterone secretion [27]. The observation that after birth the rate of SC proliferation in those ani- 

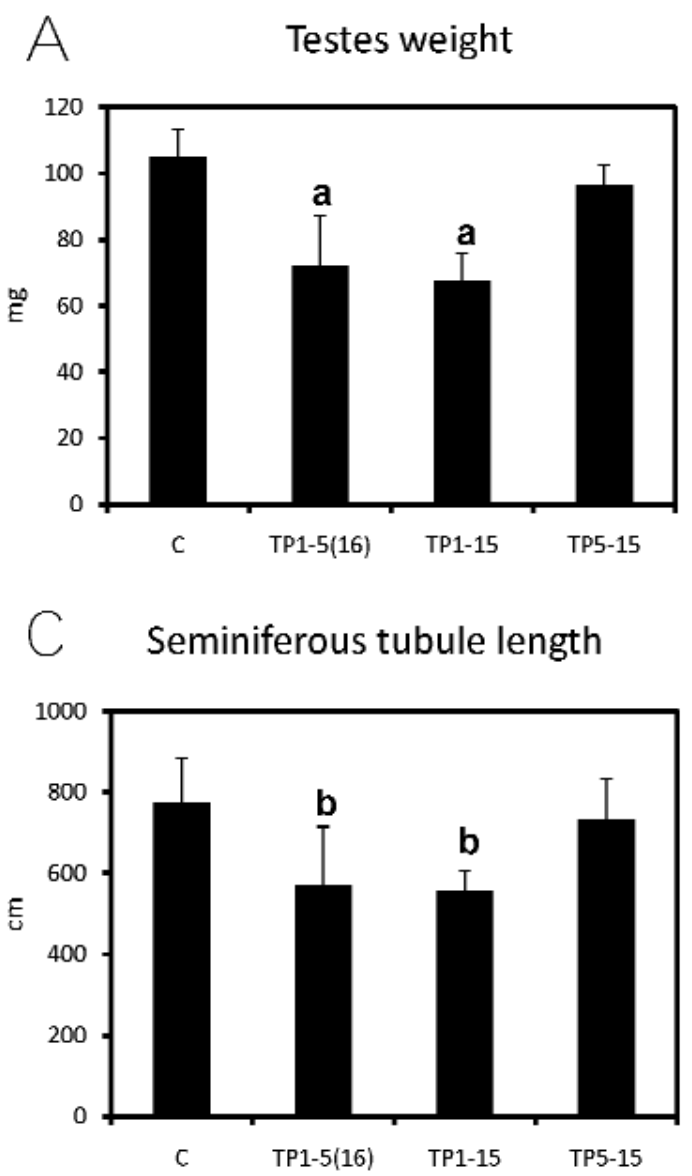
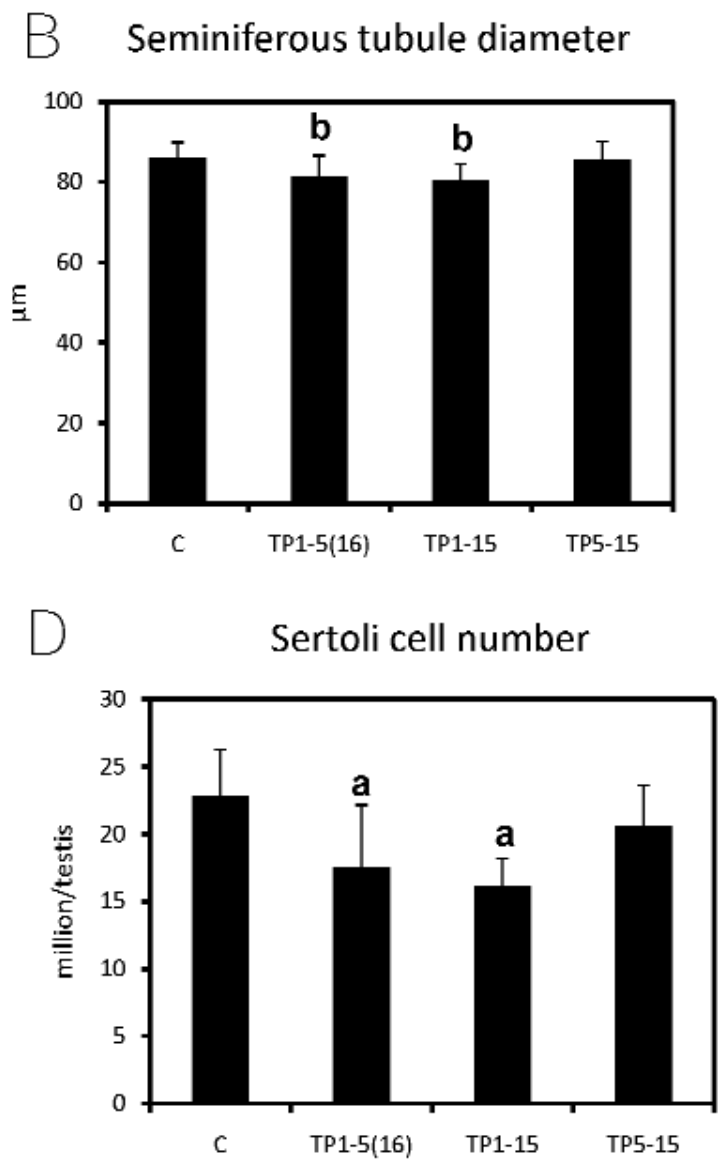

Fig. 1. Testes weight $(\mathbf{A})$, seminiferous tubule diameter $(\mathbf{B})$, seminiferous tubule length $(\mathbf{C})$ and Sertoli cell number $(\mathbf{D})$ in 16 -day-old rats treated with vehicle $(\mathbf{C})$ or with $2.5 \mathrm{mg}$ of tes-tosterone propionate (TP) in different periods of neonatal life [TP1-5(16), TP1-15, TP515]. Values are means \pm SD. ap $<0.001 ; \mathrm{bp}<0.05$ vs. $\mathrm{C}$

mals was reduced with concomitant reduction of testosterone [28-30] suggested the possible involvement of androgens. However, Singh and Handelsman [31] have shown that neonatal treatment of hpg mice with testosterone does not change subsequent numbers of SC in the adult mice. So, the more probable is that the reduced number of SC in neonatal hpg testes was due to lack of FSH. Generation of SC-selective double knockout mouse for both androgen and FSH receptor (FSHRKO-SCARKO mouse) [32] revealed that only FSH is of importance in terms of direct effects on SC proliferation with no synergistic or additive effect of androgen.

Ebling et al. [33] suggested that estradiol may be important in the initial development of male reproductive axis. Estradiol may contribute indirectly to the proliferation and maturation of Sertoli cell via the stimulation of FSH secretion, and is also likely to have direct paracrine actions within the testis augmenting the action of FSH on Sertoli cell function as shown previously [4,7]. It has been demonstrated recently that physiological levels of estrogen promotes proliferation of cultured immature rat SC [34]. Though, estrogens are usually recognized as factor inducing detrimental effects on SC number and function, it is suggested that this effect may depend on the blood concentration of the hormone $[35,36]$. In our study continuous administration of TP increased blood level of estradiol but FSH secretion did not increased suggesting that estradiol might participate in inhibition of testicular growth and SC number independently of FSH secretion.

After neonatal TP administration except from the decrease in FSH levels on $6^{\text {th }}$ PND, a dramatic decrease of estradiol level was observed. The main sites of estrogen synthesis in the fetal and postnatal testis of rodents are SC $[18,24]$. The possible explanation of the decrease in estradiol level by TP might be the inhibition of FSH secretion or enhanced dislocation of aromatase from SC into Leydig cells [18]. Namely, the same dose of TP did not cause changes in FSH levels on $16^{\text {th }} \mathrm{PND}$, indicating either decreased 
sensitivity of the pituitary to negative feedback inhibition during postnatal development $[37,38]$ or increased aromatization of testosterone in Leydig cells, a new setting of estradiol production.

In conclusion, presented here study revealed highest concentration of estradiol in first 5 neonatal days that naturally decreased during further development. It is likely that TP administration during the first 5 PNDs resulted in decreased testes growth and SC number through inhibition of FSH secretion. During further infantile period testosterone through increased aromatisation to estradiol might participate to the sustained inhibition of testes growth and decreased SC number.

Acknowledgements: This work was supported by grants of Medical University of Lodz no.: 502-11-565, 503-1089-2 and 503-1089-3.

\section{References}

[1] Jorgensen N, Asklund C, Carlsen E, Skakkebaek NE. Coordinated European investigations of semen quality: results from studies of Scandinavian young men is a matter of concern. Int $J$ Androl. 2006;29:54-61; discussion 105-108.

[2] Orth JM, Gunsalus GL, Lamperti AA. Evidence from Sertoli cell-depleted rats indicates that spermatid number in adults depends on numbers of Sertoli cells produced during perinatal development. Endocrinology. 1988;122:787-794.

[3] Wang ZX, Wreford NG, De Kretser DM. Determination of Sertoli cell numbers in the developing rat testis by stereological methods. International Journal of Andrology. 1989;12:58-64.

[4] Kula K, Walczak-Jedrzejowska R, Slowikowska-Hilczer J, Oszukowska E. Estradiol enhances the stimulatory effect of FSH on testicular maturation and contributes to precocious initiation of spermatogenesis. Mol Cell Endocrinol. 2001;178:89-97.

[5] Allan CM, Garcia A, Spaliviero J, Zhang FP, Jimenez M, Huhtaniemi I, Handelsman DJ. Complete Sertoli cell proliferation induced by follicle-stimulating hormone (FSH) independently of luteinizing hormone activity: evidence from genetic models of isolated FSH action. Endocrinology. 2004;145:1587-1593.

[6] Johnston H, Baker PJ, Abel M, Charlton HM, Jackson G, Fleming L, Kumar TR, O'Shaughnessy PJ. Regulation of Sertoli cell number and activity by follicle-stimulating hormone and androgen during postnatal development in the mouse. Endo-crinology. 2004;145:318-329.

[7] Walczak-Jedrzejowska R, Slowikowska-Hilczer J, Marchlewska K, Kula K. Maturation, proliferation and apoptosis of seminal tubule cells at puberty after administration of estradol, follicle stimulating hormone or both. Asian J Androl. 2008;10:585-592.

[ 8] Scott HM, Hutchison GR, Mahood IK, Hallmark N, Welsh M, De Gendt K, Verhoeven G, O'Shaughnessy P, Sharpe RM. Role of androgens in fetal testis development and dysgenesis. Endocrinology. 2007;148:2027-2036.

[ 9] Recabarren SE, Rojas-Garcia PP, Recabarren MP, Alfaro VH, Smith R, Padmanabhan V, Sir-Petermann T. Prenatal testosterone excess reduces sperm count and motility. Endocrinology. 2008;149:6444-6448.

[10] Tan KA, De Gendt K, Atanassova N, Walker M, Sharpe RM, Saunders PT, Denolet E, Verhoeven G. The role of androgens in sertoli cell proliferation and functional maturation: studies in mice with total or Sertoli cell-selective ablation of the androgen receptor. Endocrinology. 2005;146:2674-2683.
[11] You L, Sar M. Androgen receptor expression in the testes and epididymides of prenatal and postnatal Sprague-Dawley rats. Endocrine. 1998;9:253-261.

[12] Słowikowska-Hilczer J, Kula K. Porównanie wpływu różnych dawek benzoesanu estradiolu, propionianu testosteronu oraz ludzkiej gonadotropiny łożyskowej na zapoczatkowanie spermatogenezy u szczura. Ginekologia Polska. 1994;65:53-57.

[13] Robaire B, Ewing LL, Irby DC, Desjardins C. Interactions of testosterone and estradiol-17 beta on the reproductive tract of the male rat. Biol Reprod. 1979;21:455-463.

[14] Clermont Y, Perey B. Quantitative study of the cell population of the seminiferous tubules in immature rats. Am J Anat. 1957; 100:241-267.

[15] Abercrombie M. Estimation of nuclear population from microtome sections. Anat Rec. 1946;238-247.

[16] Marshall GR, Plant TM. Puberty occurring either spontaneously or induced precociously in rhesus monkey (Macaca mulatta) is associated with a marked proliferation of Sertoli cells. Biol Reprod. 1996;54:1192-1199.

[17] Weniger JP, Chouraqui J, Zeis A. Production of estradiol by the fetal rat testis. Reprod Nutr Dev. 1993;33:121-127.

[18] Papadopoulos V, Carreau S, Szerman-Joly E, Drosdowsky MA, Dehennin L, Scholler R. Rat testis 17 beta-estradiol: identification by gas chromatography-mass spectrometry and age related cellular distribution. Journal of Steroid Biochemistry. 1986;24:1211-1216.

[19] Li H, Papadopoulos V, Vidic B, Dym M, Culty M. Regulation of rat testis gonocyte proliferation by platelet-derived growth factor and estradiol: identification of signaling mechanisms involved. Endocrinology. 1997;138:1289-1298.

[20] Kula K. Induction of precocious maturation of spermatogenesis in infant rats by human menopausal gonadotropin and inhibition by simultaneous administration of gonadotropins and testosterone. Endocrinology. 1988;122:34-39.

[21] Miura T, Miura C, Ohta T, Nader MR, Todo T, Yamauchi K. Estradiol-17beta stimulates the renewal of spermatogonial stem cells in males. Biochem Biophys Res Com-mun. 1999;264:230-234.

[22] Meehan T, Schlatt S, O'Bryan MK, de Kretser DM, Loveland KL. Regulation of germ cell and Sertoli cell development by activin, follistatin, and FSH. Dev Biol. 2000;220:225-237.

[23] Boitani C, Stefanini M, Fragale A, Morena AR. Activin stimulates Sertoli cell proliferation in a defined period of rat testis development. Endocrinology. 1995;136:5438-5444.

[24] Tsai-Morris CH, Aquilano DR, Dufau ML. Cellular localization of rat testicular aromatase activity during development. Endocrinology. 1985;116:38-46.

[25] Bourguiba S, Genissel C, Lambard S, Bouraima H, Carreau $\mathrm{S}$. Regulation of aromatase gene expression in Leydig cells and germ cells. J Steroid Biochem Mol Biol. 2003;86:335343.

[26] Walczak-Jedrzejowska R, Slowikowska-Hilczer J, Marchlewsk K, Oszukowska E, Kula K. During seminiferous tubule maturation testosterone and synergistic action of FSH with estradiol support germ cell survival while estradiol alone has proapoptotic effect. Folia Histochem. Cytobiol. 2007;45 Suppl 1:S59-64.

[27] Cattanach BM, Iddon CA, Charlton HM, Chiappa SA, Fink G. Gonadotrophin-releasing hormone deficiency in a mutant mouse with hypogonadism. Nature. 1977;269:338-340.

[28] O'Shaughnessy PJ, Baker P, Sohnius U, Haavisto AM, Charlton HM, Huhtaniemi I. Fetal development of Leydig cell activity in the mouse is independent of pituitary gonadotroph function. Endocrinology. 1998;139:1141-1146.

[29] O'Shaughnessy PJ, Sheffield JW. Effect of testosterone on testicular steroidogenesis in the hypogonadal (hpg) mouse. J Steroid Biochem. 1990;35:729-734. 
[30] Baker PJ, O'Shaughnessy PJ. Role of gonadotrophins in regulating numbers of Leydig and Sertoli cells during fetal and postnatal development in mice. Reproduction. 2001;122:227234.

[31] Singh J, Handelsman DJ. Neonatal administration of FSH increases Sertoli cell numbers and spermatogenesis in gonadotropindeficient (hpg) mice. $J$ Endocrinol. 1996;151:37-48.

[32] Abel MH, Baker PJ, Charlton HM, Monteiro A, Verhoeven G, De Gendt K, Guillou F, O'Shaughnessy PJ. Spermatogenesis and sertoli cell activity in mice lacking sertoli cell receptors for follicle-stimulating hormone and androgen. Endocrinology. 2008;149:3279-3285.

[33] Ebling FJ, Nwagwu MO, Baines H, Myers M, Kerr JB. The hypogonadal (hpg) mouse as a model to investigate the estrogenic regulation of spermatogenesis. Hum Fertil (Camb). 2006;9:127-135.

[34] Lucas TF, Siu ER, Esteves CA, Monteiro HP, Oliveira CA, Porto CS, Lazari MF. 17beta-estradiol induces the translocation of the estrogen receptors ESR1 and ESR2 to the cell membrane, MAPK3/1 phosphorylation and proliferation of cultured immature rat Sertoli cells. Biol Reprod. 2008;78:101-114.
[35] Atanassova N, McKinnell C, Turner KJ, Walker M, Fisher JS, Morley M, Millar MR, Groome NP, Sharpe RM. Comparative effects of neonatal exposure of male rats to potent and weak (environmental) estrogens on spermatogenesis at puberty and the rela-tionship to adult testis size and fertility: evidence for stimulatory effects of low estrogen levels. Endocrinology. 2000;141:3898-3907.

[36] Gancarczyk M, Paziewska-Hejmej A, Carreau S, Tabarowski Z, Bilinska B. Dose- and photoperiod-dependent effects of 17beta-estradiol and the anti-estrogen ICI 182,780 on testicular structure, acceleration of spermatogenesis, and aromatase immunoexpression in immature bank voles. Acta Histochem. 2004;106:269-278.

[37] Huhtaniemi IT, Warren DW, Catt KJ. Regulation of infant and developing rat testicu-lar gonadotropin and prolactin receptors and steroidogenesis by treatments with human chorionic gonadotropin, gonadotropin-releasing hormone analogs, bromocriptine, prolactin, and estrogen. Biol Reprod. 1985;32:721-732.

[38] Becu-Villalobos D, Gonzalez Iglesias A, Diaz-Torga G, Hockl P, Libertun C. Brain sexual differentiation and gonadotropins secretion in the rat. Cell Mol Neurobiol. 1997; 17:699-715 